Original Research Article

\title{
Searching alternatives to plastic with special reference to Indian rural sector
}

Khan, Subhendu ${ }^{1}$; Dutta, Joystu ${ }^{2}$ and Choudhury, Moharana ${ }^{3}$

${ }^{1}$ Department of Economics, Bankura Christian College, Bankura, West Bengal

${ }^{2}$ Department of Environmental Science, Sarguja University, Ambikapur, Chhattisgarh

${ }^{3}$ Department of Environmental Science, Tezpur University, Tezpur, Assam

Corresponding Author: joystu.dutta@gmail.com

\section{A R T I C L E I N F O}

Received: 21 January 2018 | Accepted: 22 April 2018 | Published Online: 15 August 2018

DOI: $10.31786 / 09756272.18 .9 .1 .119$

EOI: $10.11208 /$ essence.18.9.1.119

Article is an Open Access Publication.

This work is licensed under Attribution-Non Commercial 4.0 International

(https://creativecommons.org/licenses/by/4.0/)

CThe Authors (2018). Publishing Rights @ MANU-ICMANU \& ESSENCE-IJERC.

\begin{abstract}
A B S T R A C T
The use of Plastic has become a very essential material in our day to day life and plays a vital role in human comfort. But due to the non-biodegradable property of plastic, it has become a major pollution concern throughout the world. In this paper the problems associated with plastic material, their impact on environment and the alternatives of plastic derivatives were discussed. This paper will be helpful to spread awareness about plastic pollution
\end{abstract}

\section{K E Y W O R D S}

Plastic pollution | polythene ban | eco-friendly products

\section{I T A T I O N}

Khan, Subhendu; Dutta, Joystu and Choudhury, Moharana (2018): Searching alternatives to plastic with special reference to Indian rural sector. ESSENCE Int. J. Env. Rehab. Conserv. IX (1): 162165. 


\section{Introduction}

UN celebrated this year's Environmental day with the moto of 'Plastic Free World', Humans are heavily dependant on plastic and all its derivatives. Plastic and its' associated derivatives have become an inseperable part of modern life. However, the question is how much we are safe? Can we imagine a world without plastic? Can we think of a world where we can design, develop and use alternatives to plastics such as paper, jute, bagasse, cotton, recyclable materials.

\section{Problems related to Plastic and Thermocols}

Plastic is a versatile material but it lacks proper degradation techniques. Thus, it is a potential polluter and carcinogenic in nature. Plastic chokes global environmental resources leading to major setbacks in maintating the pristine character of natural resources across the globe; seas and oceans, wetlands, forests, deserts and grasslands. Plastic pollution is globally distributed across all oceans due to its properties of buoyancy and durability (CRIJAF, 2013; Eriksen et al., 2014) and the sorption of toxicants to plastic while traveling through the environment have led some researchers to claim that synthetic polymers in the ocean should be regarded as hazardous waste (IJSG, 2013). Erikson et al., (2014) reports that more than 5 Trillion Plastic Pieces Weighing over 250,000 tons afloat across the world's oceans (IPCC, 2005).

It is one of the principal polluting material for large cities leading to complete damage of waterways and drainage networks. One of the brilliant examples from India is that of Mumbai; the commercial capital of the country. Rampant development and failure to curb the menace of plastic waste has contributed to complete blockage of megacity's drainage system resulting in urban floods and heavy casualties every monsoon. Similar such problems are being faced in the oceans and rivers leading to degradation of the biodiversity. Plastic and its' derivatives also contribute to groundwater pollution and blocks under surface water networks thus contaminating drinking water sources. Environmental health and disease is nega- tively affected due to plastic menace. It is a high time we must search for potential alternatives all form of plastic and associated derivatives.

Thermocol contains an important thermoplastic compound called Polystyrene obtained from polymerisation of styrene or phenylethene. The chemical properties of phenylethene are identical to polythene. It responds very slowly to decomposition in soil. Thermocol sheets are injurious to health and has associated side effects. Mr. Ramachandra, Chairman of the Karnataka State Pollution Control Board (KSPCB), agreed and said that thermocol is the biggest threat to solid waste handling, as it cannot be recycled. It has known carcinogenic impacts if burned open air. Comparatively, thermocol is ecologically more dangerous than plastic, but for the quantity in circulation. People might be affected by bacterial infection, skin allerigies and gastrointestinal problems. Most of us have no idea that food served in disposable plates can be contaminated and result in health problems. People dump those products in nullahs which choke sewerage outlets. Such products do not decompose even after 100 years. The hazardous chemicals emitted from the material after burning can damage the ozone layer. Several countries have already stated that thin plastic bags should be banned immediately. Fortunately, some states also see the seriousness of this problem. Maharashtra has imposed $100 \%$ ban on plastic. Several states are following the same path.

\section{Recommendations}

Using eco-friendly alternatives to plastic might reduce the problem associated with polythene and all its' derivatives. Using alternatives such as sal plates, paper plates, cloth bags, jute bags has no such problems. These eco-friendly alternatives will improve small scale industries and MSME. A group of people can able to earn monthly upto 5000 rupees by collecting and stitching them withtiny wooden sticks. In India making sal thali is a traditional economic activity of rural areas especially in states of Eastern and Central India such as Bihar, Jharkhand, Chhattisgarh, 
Odisha and Madhya Pradesh. It is sold at Rs 2030 per hundred in market. Value addition of sal leaves are main livelihood activity of rural areas of West Bengal, U.P, A.P, Jhar khand and Odissa. Collection of sal leaf is generally done by women and children of forest fringe communities. These people have no land for cultivation or grazing animals. There is an urgent need to develop these rural based industries for strengthening of village economy. There is a necessity to establish market linkages for these small scale industries across India. This would further encourage rural entre preneurship leading to decrease in migration trends. The problem of labor unrest in unorganized labor sectors would inturn also be reduced as a result of holistic development of rural economy. Forest based livelihood opportunities would encourage establishment of forest plantations on a large scale. This would have a positive impact on large scale afforestation under Green India Mission. Forests being the carbon source and sink act as major carbon pools on earth's surface. Mega forest plantations contribute to the microenvironment as well leading to better weather parameters such as increased rainfall, decrease in droughts, refilling of forest reservoirs and contributes to the holistic development of biodiversity of a specific region.

Jute bags can act as potential alternatives to plastic bags. Jute is biodegradable and $100 \%$ compostable. Jute (Corchorus capsularis and Corchorus olitorius), is lignocellulosic, bast fibre plant next to cotton in importance. Jute is a natural vegetable fibre made from the outer stem and skin of the jute plant. It is also known as 'the golden fibre' due to its shiny golden colour and financial worth. The use of jute bags instead of plastic bags has plethora of advantages. Jute has a very low ecological footprint and contributes effectively to sequester carbon. Manna et al. studied that under Jute-rice-wheat cropping system, the carbon sequestration potential is (1.45-3.33) $\mathrm{Mg} \mathrm{C} \mathrm{ha}^{-1}[5]$. As per report of International Jute Study Group one hectare of jute plants consumes about 15 MT $\mathrm{CO}_{2}$ and liberates $11 \mathrm{MT}$ of $\mathrm{O}_{2}$ in only 120 days [6]. In carbon sequestration, biomass is measured as dry weight and carbon is taken to account for 50 per cent of dry weight [6][7][8][9]. Through jute cultivation in 0.80 million hectare area, India may reduce about 12 million tonnes of carbon dioxide from atmosphere every year which can be valued at 1080 crores INR [10]. The CER (certified emission reduction) revenues per hectare out of jute cultivation can go to the jute growers or may be shared proportionately with jute industries and farmers. Potential Jute agroecosystems can also be utilised for development of CDM A/R (afforestation/reforestation) projects in our country thus contributing to reduction in greenhouse gas levels across a long term scenario.

\section{Conclusion}

Plastic though considered as a wonder material has proved to be a real challenge in maintaining sustainable development indices. Complete and stepwise ban of plastic is mandatory across India and around the globe. Various socio-economicpolitical issues need to be addressed in order to maintain viability of the burning problem across a changing timescale. However, the situation has more worsened in recent times. It is high time to search for eco-friendly alternatives such as cotton, jute and other forest based materials that would inturn help in sustainable forest management.

\section{References}

CRIJAF (2013): Vision 2050. ICAR-Central Research Institute for jute and fibre crops, Kolkata (W.B.) INDIA.

Eriksen, M.; Lebreton, L. C. M.; Carson, H. S.; Thiel, M.; Moore, C. J. and Borerro, J. C. (2014): Plastic Pollution in the World's Oceans: More than 5 Trillion Plastic Pieces Weighing over 250,000 Tons Afloat at Sea. PLoS One, 9(12): e111913. https:// doi.org/10.1371/journal.pone.0111913.

IJSG (2013). Carbon credit of jute and sustainable environment, International jute study group. Jute Matter, 1:1-2.

IPCC (2005): IPCC Good practice for LULUCF Sector. Intergovernmental Panel on Climate Change. University of Cambridge press, London. 
Juwarkar, A. A.; Varghese, A. O.; Singh, S. K.; Aher, V. V. and Thawale, P. R. (2011): Carbon sequestration potential in above ground biomass of natural reserve forest of central India. Internat. J. Agric. Res. \& Rev.,1:80-86

Losi, C. J.; Siccama, T. G.; Condit, R. and Morales, J. E. (2003): Analysis of alternative methods for estimating carbon stock in young tropical plantations. Forest Ecol. \& Mgmt., 184: 355-368.

Manna, M. C.; Swarup, A. and Wajari, R. H. (2005): Long-term effect of fertilizer and manure application on soil organic carbon storage, soil quality and yield sustainability under sub-humid and semi-arid tropical India. Field Crops Res., 93: 264-280.

Mato, Y.; Isobe, T.; Takada, H.; Kanehiro, H. and Ohtake, C. (2001): Plastic resin pellets as a transport medium for toxic chemicals in the marine environment. Environ Sci Technol, 35:318-324.

Rochman, C.; Browne, M.; Halpern, B.; Hentschel, B. and Hoh, E. (2013): Classify plastic waste as hazardous. Nature, 494:169171.

Teuten, E.; Rowland, S.; Galloway, T. and Thompson, R. (2007): Potential for plastics to transport hydrophobic contaminants. Environ Sci Technol, 41:7759-7764.

Timothy, P.; Walker, S. and Brown, S. (2005): Land use, land use change and forestry projects, Winrock International. 